\title{
Textile wing fabric for emergency response UAS
}

\author{
DOI: 10.35530/IT.071.04.1762
}

\section{ABSTRACT - REZUMAT}

\section{Textile wing fabric for emergency response UAS}

The fabrics used to manufacture parachutes and paragliders must have several specific characteristics: the mass of fabric per unit of surface must be low while the other physical-mechanical characteristics (the axial breaking strength load, the relative and absolute elongation, the tear resistance of the fabric and the assemblies, air permeability) must have high values. The paper deals with the analysis of qualitative aspects of several parachute fabrics that are used as a baseline in the development of a novel fabric. The results of experiments have materialized in statistical data, diagrams and graphs and their interpretation leads to the determination of the fabric variant that best meets the requirements of the destination. The destination is a patent pending inflatable wing design that utilizes a single skin construction and solid reinforcements in the sewing for shape stability. It is worth noting that the experimental results were compared with values indicated in specific international testing norms.

Keywords: parachute, paraglider, single sail, technical textile, fabric testing

\section{Țesătura aripii unui UAS pentru situații de urgență}

Țesăturile utilizate în realizarea parașutelor și parapantelor trebuie să aibă câteva caracteristici specifice: masa țesăturii pe unitatea de suprafață trebuie să fie scăzută, în timp ce celelalte caracteristici fizico-mecanice (rezistența la rupere axială, alungirea relativă și absolută, rezistența la rupere a materialului și a asamblărilor, permeabilitatea la aer) trebuie să înregistreze valori ridicate. Lucrarea tratează analiza aspectelor calitative ale mai multor țesături pentru parașută, care sunt utilizate ca bază în dezvoltarea unei țesături noi. Rezultatele experimentelor s-au materializat în date statistice, diagrame și grafice, iar interpretarea acestora duce la determinarea variantei de țesătură care corespunde cel mai bine cerințelor impuse de domeniul de utilizare. Domeniul de utilizare este o aripă textilă brevetabilă, care utilizează o singură pânză extrados și întărituri solide în asamblare pentru stabilizarea formei. De remarcat că rezultatele experimentale au fost comparate cu valorile indicate în normele internaționale specifice de testare.

Cuvinte-cheie: parașută, parapantă, aripă, textile tehnice, testarea materialului

\section{INTRODUCTION}

The laws of mechanics and aerodynamics apply to the performance and stress analysis of parachute systems. However, the textile fabrics used in parachute construction have distinctly different mechanical and environmental characteristics than metals or composites.

This paper depicts the early phase in the research development for an integrated support system tailored for emergency response actions and remote sensing. In this phase we try to develop a fabric that is tailored for use in the manufacturing process of a paraglider type wing design [1] that utilizes a single skin construction [2] and solid reinforcements in the sewing for shape stability.

In order to achieve this we used as a baseline several commercial fabrics and tried to determine the best combination of yarn, weave and finishing method in order to best suite our paraglider wing.
We mention that this is a preliminary work and is subject to change if the prototype performances will not fall within the projected limits.

\section{MATERIALS AND METHODS}

In order to establish a baseline for the fabric characteristics several readily available fabrics were analysed. The fabrics used in the testing were selected so they cover a wide array of parachute types.

Therefore we selected as material one (S1), a fabric commonly used in paraglider manufacturing. This fabric is a rather heavy fabric having polyurethane and silicone coating for UV protection.

The second material (S2) is a fabric used in most of the Ram-Air parachutes available today. It's a light fabric with polyurethane coating for zero air permeability.

The third material (S3) is a fabric with similar structure as $\mathrm{S} 2$ but without polyurethane coating. This fabric is only calendered and it is commonly referred to as F111 type fabric. This type of fabric has some air 
permeability therefore is mainly used in reserve ramair parachutes or partially on the intrados side of main parachutes.

Testing of the tear resistance of the samples was done on the Tinius Olsen Dynamometer H5KT dynamometer (figure 1). The device is designed to test a wide range of materials (yarns, fabrics, leather) for traction, flexion, and assembly strength (made by sewing, thermofusion etc.).

Further on we extracted yarns from the fabrics in order to determine the yarn characteristics.

In table 1 are listed the test results and methods used for these fabrics.

The values of the structural parameters of the fabrics (air permeability, mass, thickness, etc.) were used in conjunction with the extracted yarn test results to determine the multivariate regression equations in which the independent variables were considered the breaking strengths in warp and weft (figure 2). In this figure on $x$-axis we have the displacement of the clamping device, in $\mathrm{mm}$. We notice a very inconsistent reading, as if the yarn is partially slipping, compared

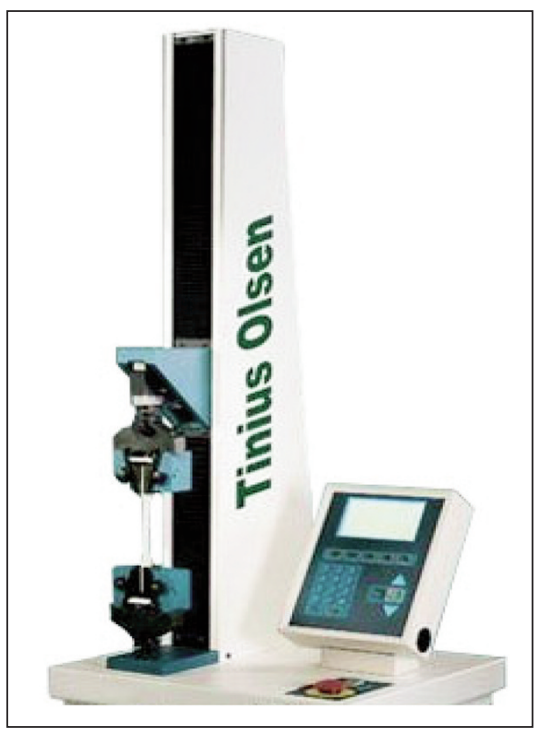

Fig. 1. H5KT dynamometer

with the clean regular Nylon 6.6 yarn. We suspect this to be because of the residual polyurethane coat-

\begin{tabular}{|c|c|c|c|c|c|}
\hline \multicolumn{6}{|c|}{ TEST RESULTS } \\
\hline \multicolumn{2}{|l|}{ Test Name } & s1 & S2 & S3 & Testing method \\
\hline \multicolumn{2}{|l|}{ Fabric mass $\left(\mathrm{g} / \mathrm{m}^{2}\right)$} & 59 & 47 & 40 & SR EN 12127:2003 \\
\hline \multirow[t]{2}{*}{ Yarn count (threads/10 cm) } & Warp & 474 & 534 & 532 & \multirow{2}{*}{$\begin{array}{l}\text { SR EN 1049-2:2000; } \\
\text { Method A, B }\end{array}$} \\
\hline & Weft & 432 & 508 & 524 & \\
\hline \multirow[t]{2}{*}{ Yarn linear density (DTex den) } & Warp & $61.8(55.62)$ & $41.2(37.08)$ & $32.6(29.34)$ & \multirow{2}{*}{$\begin{array}{l}\text { SR 6430:2012; } \\
\text { Method A }\end{array}$} \\
\hline & Weft & $69.4(62.46)$ & $46.4(41.76)$ & $32.2(28.98)$ & \\
\hline \multirow[t]{2}{*}{ Yarn breaking strength $(\mathrm{N})$} & Warp & 1.943 & 1.728 & 1.522 & \multirow{4}{*}{$\begin{array}{l}\text { SR EN ISO 2062:2010 } \\
\text { Method B }\end{array}$} \\
\hline & Weft & 1.803 & 1.582 & 1.498 & \\
\hline \multirow[t]{2}{*}{ Yarn elongation at breaking force $(\%)$} & Warp & 25.64 & 38.80 & 27.87 & \\
\hline & Weft & 27.70 & 38.52 & 32.57 & \\
\hline \multirow[t]{2}{*}{ Fabric breaking strength $(\mathrm{N})$} & Warp & 541 & 431 & 450 & \multirow{4}{*}{$\begin{array}{l}\text { SR EN ISO 13934-1: } \\
2013\end{array}$} \\
\hline & Weft & 480 & 412 & 450 & \\
\hline \multirow[t]{2}{*}{ Fabric elongation at breaking force (\%) } & Warp & 24.9 & 27.8 & 27.4 & \\
\hline & Weft & 29.1 & 39.3 & 33.9 & \\
\hline \multirow[t]{2}{*}{ Fabric tearing strength $(\mathrm{N})$} & Warp & 20.7 & 66.1 & 35.8 & \multirow{2}{*}{$\begin{array}{l}\text { SR EN ISO 13937-3: } \\
2002\end{array}$} \\
\hline & Weft & 20.7 & 66.3 & 29.2 & \\
\hline \multicolumn{2}{|l|}{ Fabric bursting strength (KPa) } & 370.8 & 334.2 & 334.3 & \multirow{2}{*}{ EN ISO 13938-2/2002 } \\
\hline \multicolumn{2}{|l|}{ Fabric bursting strength (mm) } & 43.2 & 42.2 & 36.6 & \\
\hline \multicolumn{2}{|l|}{ Fabric air permeability $\left(1 / \mathrm{m}^{2} / \mathrm{s}\right)$ at $200 \mathrm{~Pa}$} & 0 & 0 & 11.57 & SR EN ISO 9237:1999 \\
\hline \multicolumn{2}{|l|}{ Raw material } & $100 \% \mathrm{PA}$ & $100 \% \mathrm{PA}$ & $100 \% \mathrm{PA}$ & SR 13231-95 \\
\hline \multicolumn{2}{|l|}{ Coating } & $\begin{array}{c}\text { PU and Silicone } \\
\text { coating }\end{array}$ & PU coating & Calendered & SR ISO 1833-95 \\
\hline \multicolumn{2}{|l|}{ Link type } & Double-ripstop & Ripstop & Ripstop & - \\
\hline \multicolumn{2}{|l|}{ Fabric image } & & & & - \\
\hline
\end{tabular}




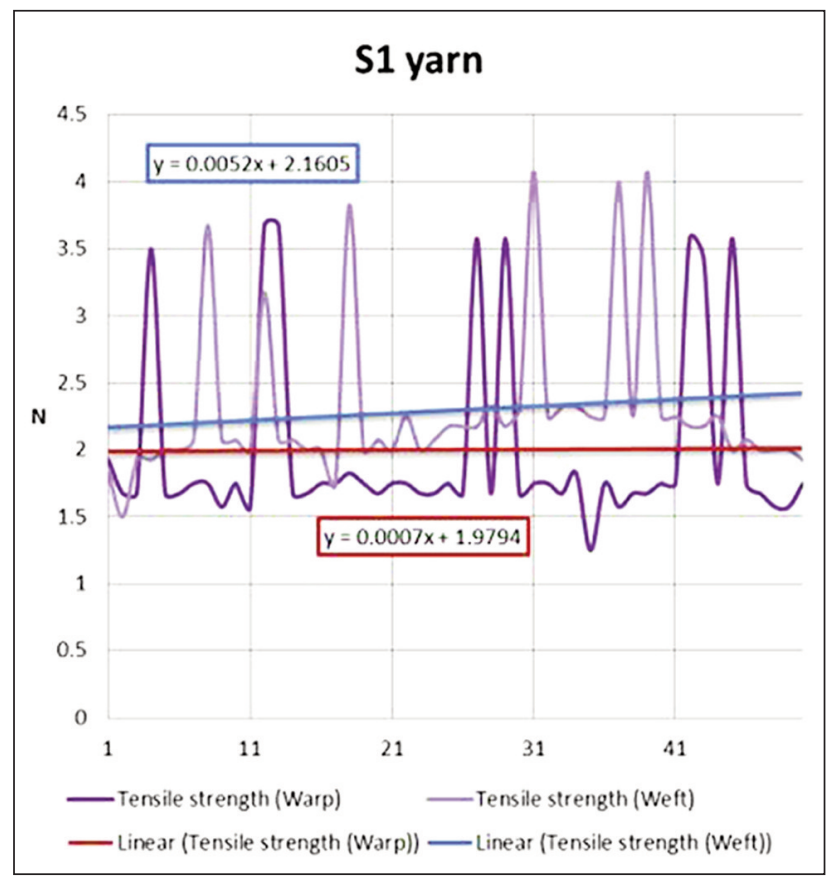

a

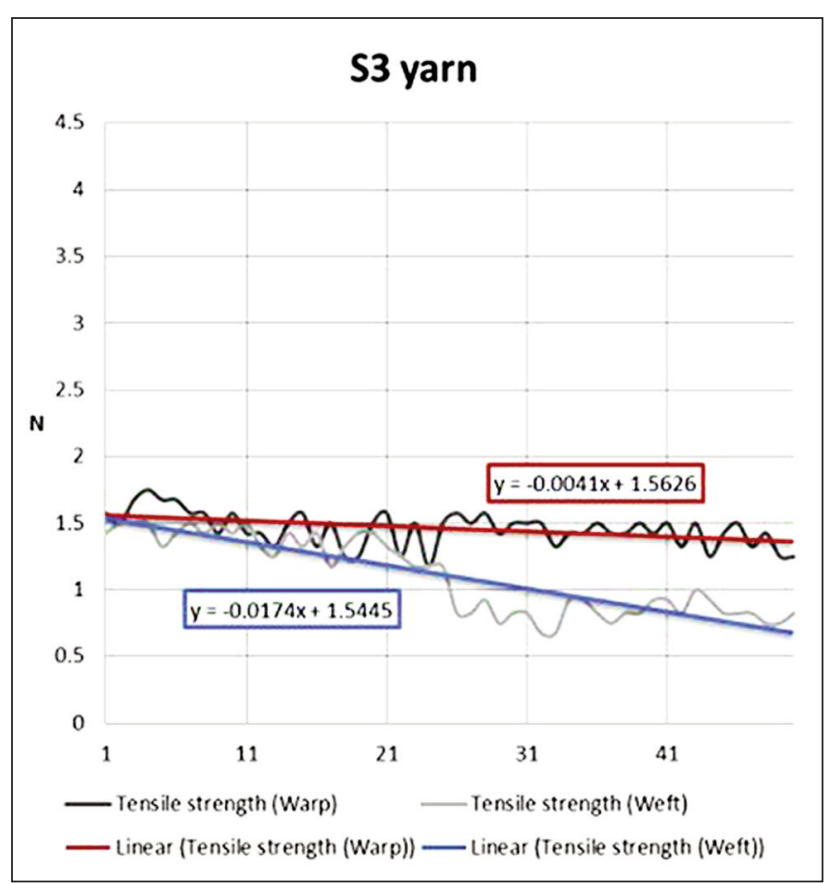

C

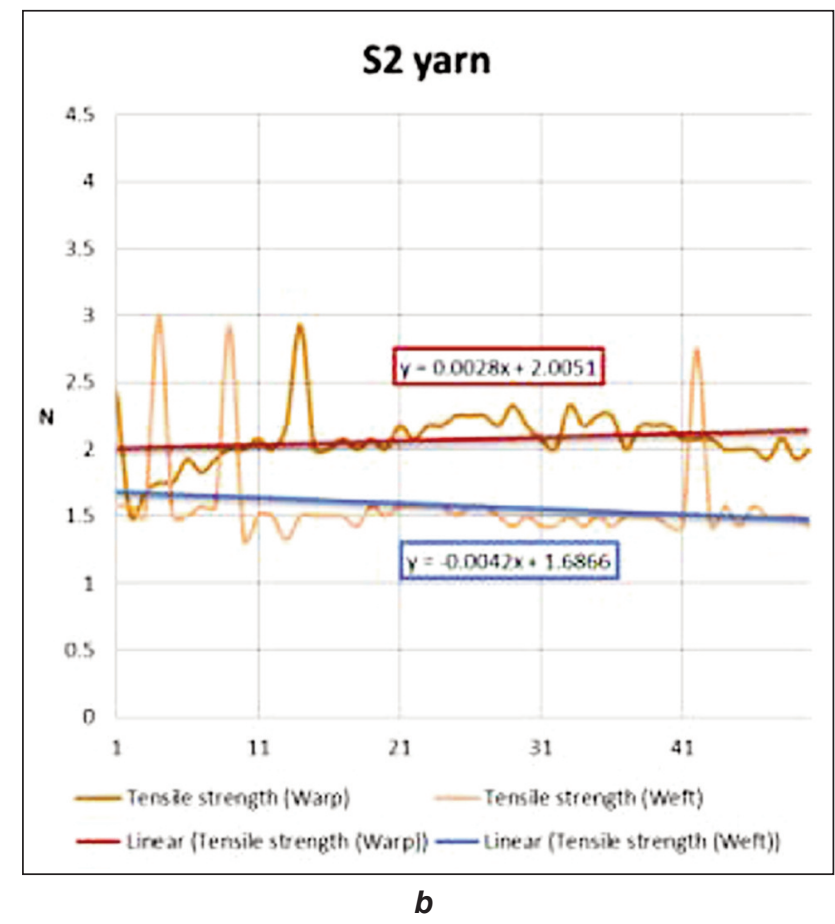

Nylon 6.6

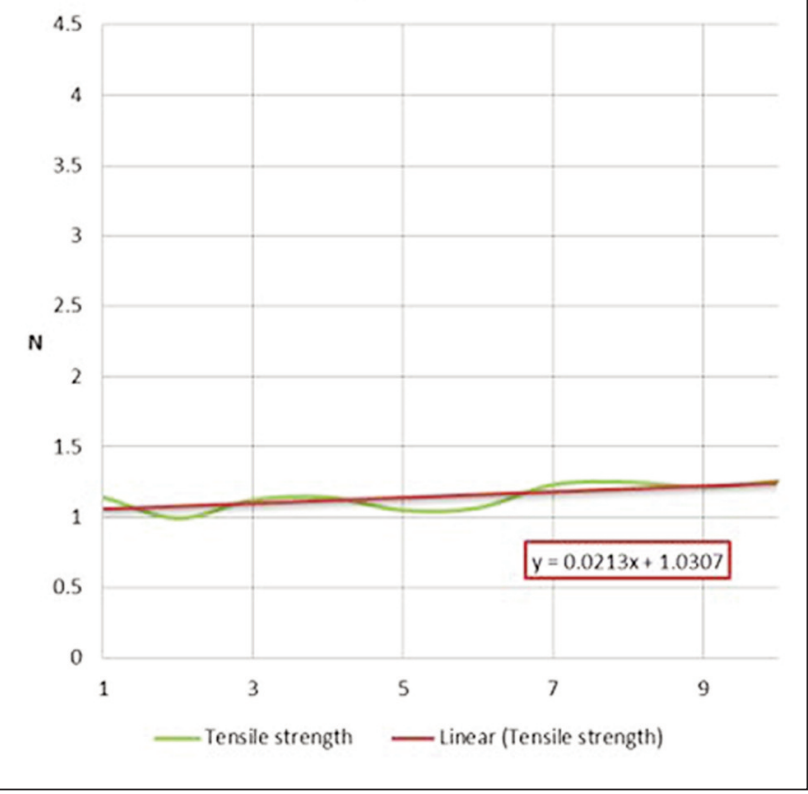

d

Fig. 2: Breaking strength and trend line for each analysed yarn: $a-\mathrm{S} 1$ yarn; $b-\mathrm{S} 2$ yarn; $c-\mathrm{S} 3$ yarn; $d-\mathrm{Nylon} 6.6$

ing present on the extracted yarns. S3 sample, that was not coated, had smaller reading spikes. A statistical smoothing of the readings puts the breaking strength of the extracted yarns roughly on a value that is double than that of the regular Nylon 6.6 yarn. This is the tell-tale sign that we are dealing with HT Nylon 6.6 yarns. At the time of the testing we did not have stocked HT Nylon 6.6 to make a direct comparison.

\section{RESULTS AND DISCUSSION}

Further on we can assess the strength transfer coefficient [4] given mathematically as:

$$
C=\frac{T f_{2}}{T f_{1}}
$$

where $T f_{1}$ is yarn tenacity before its integration in fabric expressed in N/Tex calculated with the equation:

$$
T f_{1}=\frac{F_{b k g(t)}}{T e x}
$$

$\mathrm{Tf}_{2}$ is theoretical yarn tenacity after its integration in woven structure, including the influence of the weave structure/finishing treatments and is expressed also in $\mathrm{N} / \mathrm{Tex}$ :

$$
T f_{2}=\frac{F_{b k g(t)}}{P \times b \times T e x}
$$


The strength transfer coefficient $\mathrm{C}$ for the given samples has the following values:

- S1 sample: Warp 1.14; Weft 0.97;

- S2 sample: Warp 0.78; Weft 1.03;

- S2 sample: Warp 1.16; Weft 1.56.

Closer these coefficients are from unity the more linear is the transfer rate, above one means the existing woven structure and treatment strengthens the yarn properties. From this we observed S1 and S3 structures to be superior in this regard.

One of the most important properties for these fabrics is the air permeability $[3,4]$ and we tried to reduce this by catering several aspects:

- Yarn torsion of the two systems;

- The use of specially designed connections like ripstop or double ripstop type, with a binding segment of maximum two which interrupt the tendency of the wires of one system to slide towards the wires of the other system (not recommended to use the connections D2/1, R2/1, R1/2 or P2/2).
- Finishing treatment, polyurethane coating.

Two woven types of fabrics were developed accordingly to the following weave diagrams and general characteristics:

- Yarn fiber composition: 100\% PA6.6HT;

- Yarn linear density: 30 den/32 f;

- Yarn count warp: 495 threads/10 cm;

- V1 Yarn count weft: 504 threads/10 cm (figure 3);

- V2 Yarn count weft: 508 threads/10 cm (figure 4).

Four fabric variants were developed as follows:

- a fabric with ripstop connection (V1 and V3) and

- another double-ripstop (V2 and V4).

Each connection variant was made in two finishing variants:

- calendering (V1 and V2) and

- polyurethane coating (V3 and V4) thus resulting in four variants of finished fabrics.

In table 2 are listed the test results and methods used for these finished fabrics.

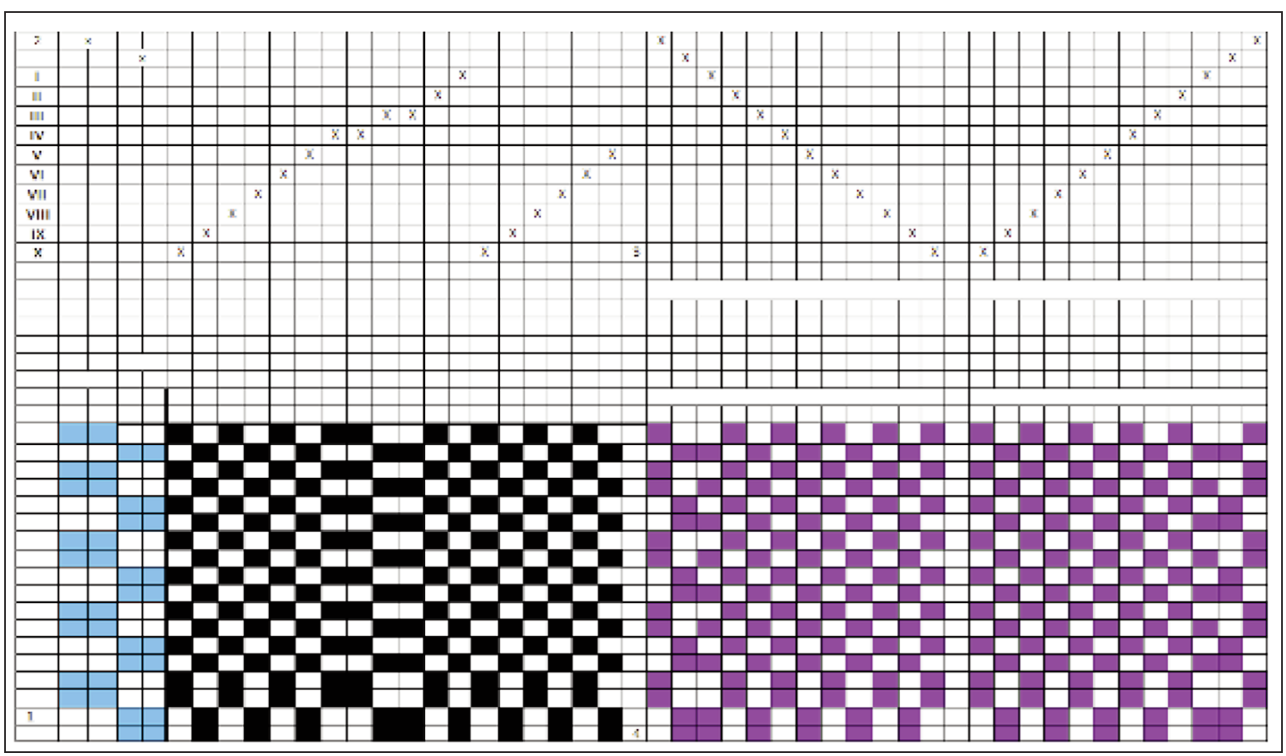

Fig. 3. Programming card for weave structure V1 (Ripstop weave)

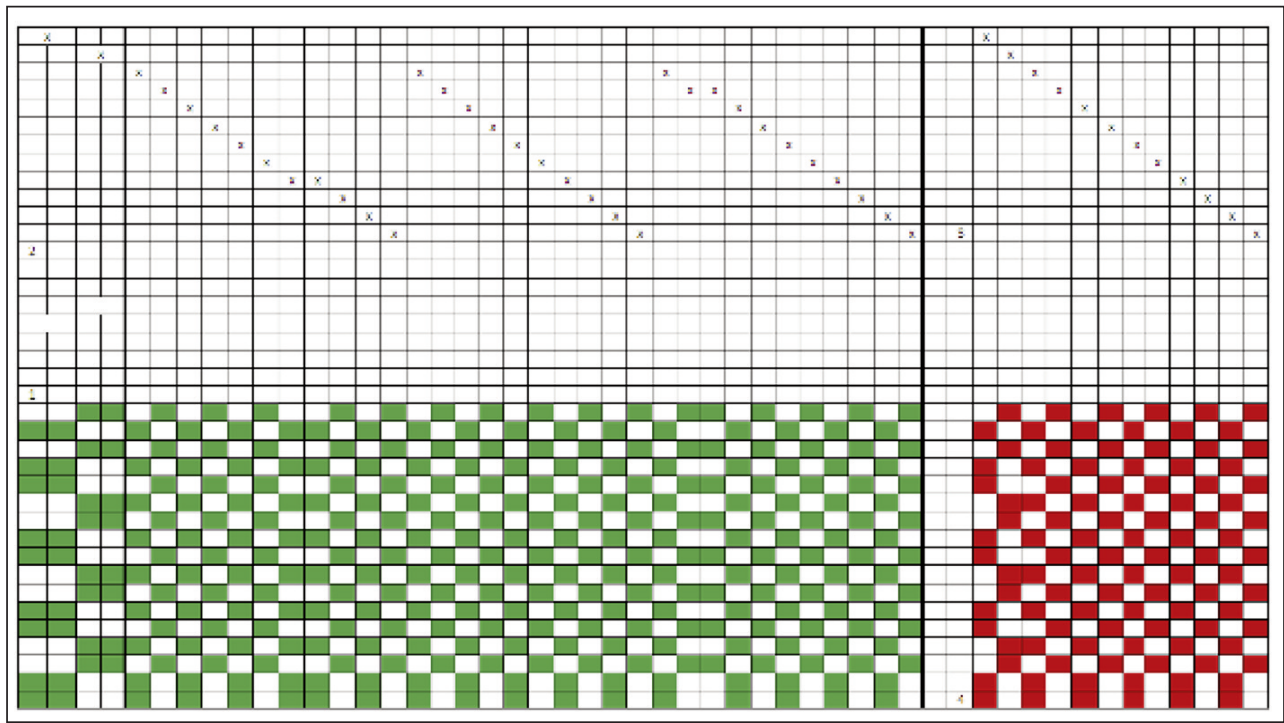

Fig. 4. Programming card for weave structure V2 (Double ripstop weave) 


\begin{tabular}{|c|c|c|c|c|c|c|}
\hline \multicolumn{7}{|c|}{ TEST RESULTS } \\
\hline \multicolumn{2}{|l|}{ Test Name } & Fabric V1 & Fabric V2 & Fabric V3 & Fabric V4 & Testing method \\
\hline \multicolumn{2}{|l|}{ Fabric mass $\left(\mathrm{g} / \mathrm{m}^{2}\right)$} & 40 & 51 & 47 & 59 & SR EN 12127:2003 \\
\hline \multirow{2}{*}{ Yarn count (threads/10 cm) } & Warp & 495 & 495 & 495 & 495 & \multirow{2}{*}{ SR EN 1049-2:2000 } \\
\hline & Weft & 504 & 508 & 504 & 508 & \\
\hline \multirow{2}{*}{ Fabric breaking strength $(\mathrm{N})$} & Warp & 440 & 554 & 422 & 541 & \multirow{4}{*}{$\begin{array}{l}\text { SR EN ISO 13934-1: } \\
2013\end{array}$} \\
\hline & Weft & 445 & 484 & 410 & 480 & \\
\hline \multirow{2}{*}{$\begin{array}{l}\text { Fabric elongation at breaking } \\
\text { force }(\%)\end{array}$} & Warp & 28.6 & 23.6 & 26.7 & 24.9 & \\
\hline & Weft & 32.7 & 26.2 & 38.4 & 29.1 & \\
\hline \multirow{2}{*}{ Fabric tearing strength $(\mathrm{N})$} & Warp & 34.4 & 21.3 & 65.2 & 20.7 & \multirow{2}{*}{$\begin{array}{l}\text { SR EN ISO 13937-2: } \\
2001\end{array}$} \\
\hline & Weft & 32.7 & 22.5 & 65.5 & 20.7 & \\
\hline \multicolumn{2}{|l|}{ Fabric bursting strength $(\mathrm{KPa})$} & 330.3 & 368.4 & 330.2 & 370.8 & \multirow{2}{*}{ EN ISO 13938-2/ 2002} \\
\hline \multicolumn{2}{|l|}{ Fabric bursting strength (mm) } & 35.4 & 36.3 & 42.5 & 43.2 & \\
\hline \multicolumn{2}{|l|}{$\begin{array}{l}\text { Fabric air permeability }\left(1 / \mathrm{m}^{2} / \mathrm{s}\right) \\
\text { at } 200 \mathrm{~Pa}\end{array}$} & 10.53 & 10.34 & 0 & 0 & SR EN ISO 9237:1999 \\
\hline \multicolumn{2}{|l|}{ Raw material } & $\begin{array}{c}100 \% \\
\text { PA66HT }\end{array}$ & $\begin{array}{c}100 \% \\
\text { PA66HT }\end{array}$ & $\begin{array}{c}100 \% \\
\text { PA66HT }\end{array}$ & $\begin{array}{c}100 \% \\
\text { PA66HT }\end{array}$ & SR 13231-95 \\
\hline \multicolumn{2}{|l|}{ Coating } & Calendered & Calendered & PU coating & PU coating & SR ISO 1833-95 \\
\hline \multicolumn{2}{|l|}{ Link type } & Ripstop & $\begin{array}{l}\text { Double- } \\
\text { ripstop }\end{array}$ & Ripstop & $\begin{array}{l}\text { Double- } \\
\text { ripstop }\end{array}$ & - \\
\hline
\end{tabular}

\section{CONCLUSIONS}

The fabric breaking strength is in line with the breaking strength of the yarn, this validates the testing methods and yarn extraction method. A strength transfer coefficient greater than one means the woven structure has higher theoretical tenacity than all the yarns combined. This means that the calendred fabric S3 woven structure amplifies better the yarn tenacity than coated fabrics; however the S1 fabric is not far behind and has way better breaking strength, lower elongation and also lower air permeability, probably because of the double-ripstop structure.

The highest yarn elongation of S2 influences in an interesting way the tearing behaviour and tearing strength results. The S2 fabric gets the highest tearing resistance due to this but is not necessarily the correct one since the fabric torn incompletely. Some threads remained in structure and influenced the results.

Due to the nature of the single sail wing, the amount of fabric used in the manufacture is almost halved therefore the fabric can be a little heavier and also can have a less than perfect air permeability because the shape is maintained by several rigid members. Thus we conclude that the fabric must use yarn of high tenacity Nylon 66; then make use of the rip-stop weave link and polyurethane coating.
The fabric variants obtained were tested and these conclusions were drawn:

- Regarding the air permeability, the most performing variants were the coated ones (V3 and V4).

- Considering the specific mass, the lightest fabric is the $\mathrm{V} 1$ variant.

- Considering the breaking resistances, all variants are in the same performance class but with significantly higher values in the case of double-ripstop variants V2 and V4. However, increased tear strength is observed in the case of the V 3 variant, this is due to the tearing mode which opposes the propagation of the rupture. This type of tearing behaviour is presented by both $\mathrm{V} 1$ and $\mathrm{V} 3$.

- Further testing is required to decide if the fabric can be functionalized with hydrophobic properties in order to expand the operational capabilities of the UAV for rainy weather or with applied heating elements for use on sub-zero temperatures or high altitude flying.

- Analysing the results and given the desirable tearing behaviour of the V3 variant, we choose this working variant for the UAV textile structure prototype manufacturing in the next stages of system design. 


\section{REFERENCES}

[1] Knache, T.W., Parachute Recovery Systems - Design Manual, Para Publishing, Santa Barbara, California, 1992

[2] Poynter, D., The Parachute Manual - A Technical Treatise on Aerodynamic Decelerators, vol. 2, Santa Barbara, California, 1984

[3] U.S. Department of Transportation, Parachute rigger handbook, FAA Flight Standards Service, 2005

[4] Cristian, I., Nauman, S., Boussu, F., Koncar, V., A Study of Strength Transfer from tow to Textile Composite Using Different Reinforcement Architectures, In: Appl. Compos. Mater., 2012, 19, 3-4, 447-458, https://doi.org/10.1007/ s10443-011-9215-x

Authors:

\section{ADRIAN SĂLIȘTEAN, CARMEN MIHAI}

National Research and Development Institute for Textiles and Leather, DCSTA,

16, Lucretiu Patrascanu Street, 030508, Bucharest, Romania

email: office@incdtp.ro

Corresponding author:

ADRIAN SĂLIȘTEAN

e-mail: adrian.salistean@incdtp.ro 